\title{
Pengaruh Penerapan Metode Demonstrasi Terhadap Keterampilan Berhitung Siswa Kelas 3 SD Negeri Kecandran 01
}

\author{
Lailatul Fitriyah*, Romirio Torang Purba ${ }^{2}$ \\ 1 Jurusan Pendidikan Guru Sekolah Dasar, Universitas Kristen Satya Wacana, Salatiga, Indonesia \\ 2 Jurusan Pendidikan Guru Sekolah Dasar, Universitas Kristen Satya Wacana, Salatiga, Indonesia
}

\begin{abstract}
The purpose of this research is to know the influence of the implementation of demonstration method to the numeracy skills of third grade students of SDN Kecandran 01 in second semester of academic year 2016/2017. This research is an experimental research. This research was conducted in two different schools namely SDN Kecandran 01 in class 3 as the experimental class and SDN Dukuh 01 in class 3 as the control class. Students of each school in class 3 as many as 32 students. Data analysis technique used in this research is ancova test using unvariet. The results showed that in the experimental class average pretest of 50, for the average posttest value of 88.59. While in the control class the average pretest value of 48.13 , for the posttest value of 79.69. The difference in the pretest value of the two classes was 1.87 , while the difference in the posttest average was 8.9. So it can be concluded that there is influence of the implementation of demonstration methods on the numeracy skills of third grade students of SDN Kecandran 01 Salatiga in the second semester of academic year 2016/2017.
\end{abstract}

Keywords:

Demonstration Method; Numeracy Skills

\section{Pendahuluan}

Undang-undang No. 20 Tahun 2003 tentang sistem pendidikan nasional menyatakan bahwa pendidikan merupakan usaha sadar dan terencana untuk mewujudkan suasana belajar dan proses pembelajaran agar peserta didik secara aktif mengembangkan potensi dirinya untuk memiliki kekuatan spiritual, keagamaan, pengendalian diri, kepribadian, kecerdasan, akhlak mulia, serta keterampilan yang diperlukan dirinya, masyarakat, bangsa dan negaranya. Namun demikian, terkadang bahwa tujuan mulia belum dapat mencapai tujuan yang ingin dicapainya. Hal ini lebih banyak diakibatkan karena proses mendidik melalui proses belajar mengajar yang masih didominasi dengan pendekatan satu arah, dimana guru sebagai pusat informasi, guru dianggap sebagai suatu kebenaran. Akibatnya siswa dikondisikan untuk harus mendengarkan dan patuh sepenuhnya apa yang dikata guru. Dalam situasi yang demikian, diduga kecerdasan, keaktifan dan kreativitas siswa yang sesungguhnya tidak dapat berkembang sesuai dengan usia perkembangannya.

Penelitian kali ini difokuskan untuk mengetahui pengaruh penerapan metode demonstrasi terhadap keterampilan berhitung siswa dalam mata pelajaran matematika. Alasan yang menjadikan peneliti memfokuskan penelitiannya pada keterampilan berhitung siswa dikarenakan keterampilan berhitung dijadikan sebagai dasar dalam pembelajaran matematika. Selain itu, dalam matematika diperlukan sebuah ketelitian, ketekunan, kesabaran, dan kritis dalam menanggapi sebuah masalah matematika. Banyak siswa beranggapan bahwa matematika itu pelajaran yang paling sulit, mengapa demikian? Karena banyak siswa yang belum paham mengenai konsep-konsep dasar dalam sebuah pemecahan masalah pada matematika. Seperti yang diungkapkan Wahyudi dan Kriswandani (2013:10), matematika adalah sebagai ilmu pengetahuan yang mempelajari konsep-konsep abstrak yang disusun dengan menggunakan simbol dan merupakan bahasa yang eksak, cermat, dan terbebas dari emosi.

Tujuan umum pendidikan matematika di SD adalah agar siswa mampu dan terampil menggunakan matematika (Susanto, 2013). Mampu dan terampil dalam menggunakan matematika maksudnya adalah siswa harus mempunyai keterampilan dalam hitung-menghitung, memecahkan masalah, memahami konsep, pola, sifat dan lainnya. Jika siswa tidak mempunyai keterampilan berhitung maka penguasaan 
dalam pembelajaran matematika sangatlah sulit, sehingga akan mempersulit dalam mencapai tujuan utama maupun tujuan umum pada pembelajaran matematika. Selain tujuan umum pendidikan matematika SD, Depdiknas (Susanto, 2013) menjabarkan tujuan secara khusus pendidikan matematika di SD seperti (1) memahami konsep matematika, menjelaskan keterkaitan antar konsep, dan mengaplikasikan konsep algoritme; (2) menggunakan penalaran pada pola dan sifat, melakukan manipulasi matematika dalam generalisasi, menyusun bukti atau menjelaskan gagasan dan pernyataan matematika; (3) memecahkan masalah yang meliputi kemampuan memahami masalah, merancang model matematika, menyelesaikan model, dan menafsirkan solusi yang diperoleh; (4) mengkomunikasikan gagasan dengan simbol, tabel, diagram atau media lain untuk menjelaskan keadaan atau masalah; dan (5) memiliki sikap menghargai penggunaan matematika dalam kehidupan sehari-hari.

Dalam tujuan umum dan tujuan khusus pendidikan matematika di SD tersebut, siswa dituntut untuk mampu dan terampil dalam memahami konsep, pola, sifat, hitung-menghitung, memecahkan masalah, dan mengkomunikasikan gagasan. Maka itu, pada penelitian ini, akan diterapkan metode demonstrasi sebagai salah satu metode pembelajaran yang dapat membantu mencapai tujuan pembelajaran tersebut. Metode demonstrasi menurut Sabri (2007:57) adalah mengajar yang memperlihatkan bagaimana proses terjadinya sesuatu, yang dapat dilakukan oleh guru atau orang lain secara sengaja. Sedangkan menurut Ekasriadi dkk., (2006:28), metode demonstrasi adalah cara untuk mempertunjukan atau memperagakan suatu objek atau proses dari suatu kejadian atau peristiwa. Jadi, metode demonstrasi adalah metode yang memperlihatkan, mempertunjukan atau memperagakan suatu proses atau cara mengerjakan sesuatu yang dapat membantu siswa menjadi lebih aktif dalam pembelajaran.

Metode demonstrasi merupakan metode pembelajaran yang sederhana. Meskipun sederhana, metode demonstrasi memiliki kelebihan dan kekurangan dalam penerapannya. Huda (2010:233) mengungkapkan kelebihan metode demonstrasi dalam pembelajaran antara lain: 1) membuat pembelajaran menjadi lebih jelas dan lebih konkret; 2) memusatkan perhatian siswa pada pembelajaran; 3) lebih mengarahkan proses belajar siswa pada materi yang sedang dipelajari; 4) lebih melekatkan pengalaman dan kesan sebagai hasil pembelajaran dalam diri siswa; 5) membuat siswa lebih mudah memahami apa yang dipelajari; 6) membuat proses pengajaran lebih menarik; 7) merangsang siswa untuk aktif mengamati antar teori dengan kenyataan; 8) membantu siswa memahami dengan jelas jalannya suatu proses atau cara kerja suatu benda; 9) memudahkan berbagai jenis penjelasan; dan 10) memperbaiki kesalahan yang terjadi dari hasil ceramah melalui pengamatan dan contoh konkret dengan menghadirkan objek sebenarnya.

Selain memiliki sepuluh kelebihan, metode demonstrasi juga memiliki beberapa kekurangan seperti yang diungkapkan oleh Huda (2010:233) antara lain: 1) metode demonstrasi mengharuskan keterampilan guru secara khusus; 2) tidak tersedianya fasilitas-fasilitas pendukung, seperti peralatan, tempat, dan biyaya yang memadahi setiap kelas; 3) memerlukan kesiapan dan perencanaan yang matang disamping waktu yang cukup panjang; 4) tidak semua benda dapat didemonstrasikan; dan 5) sukar dimengerti bila didemonstrasikan oleh guru yang kurang menguasai materi atau barang yang didemonstrasikan.

Metode demonstrasi merupakan metode pembelajaran yang sudah lama berada di dunia pendidikan. Dan metode demonstrasi berulangkali digunakan atau diterapkan dalam pembelajaran, baik itu diterapkan untuk pembelajaran agar dapat membantu guru dalam menyajikan materi ataupun diterapkan untuk penelitian saja. Metode demonstrasi yang digunakan sebagai penelitian telah dilakukan oleh Firdus (2014). Hasil penelitiannya menunjukkan bahwa terdapat pengaruh penggunaan metode demonstrasi terhadap hasil belajar cahaya dan sifat-sifatnya pada siswa kelas V SDN 100/I Pematang Gadung. Seperti yang dilakukan oleh Firdaus, Sodikin (2015) juga melakukan penelitian yang sama namun dengan hasil yang berbeda. Hasil penelitiannya menunjukkan bahwa tidak ada pengaruh penggunaan metode pembelajaran eksperimen dan demonstrasi terhadap prestasi kognitif. Jadi ada perbedaan hasil penelitian padahal keduanya meneliti hal yang sama. Beberapa hasil penelitian yang lain dengan menggunakan metode penelitian PTK menunjukkan hasil yang berbeda terhadap temuan Sodikin.

Dalam penelitian yang telah dilakukan oleh Sodikin memiliki sebuah kelemahan menurut penulis antara lain seperti 1) terlalu banyak variabel yang diteliti sehingga peneliti tidak dapat fokus terhadap variabel yang diteliti; 2) dalam melaksanakan penelitian seharusnya menggunakan kelas yang homogen sehingga dalam mengolah data lebih mudah. 3) uji analisis yang digunakan adalah uji anava, seharusnya uji analisisnya menggunakan uji ancova. Uji anava digunakan untuk menguji perbedaan rata-rata data, sedangkan dalam penelitian ini analisis yang digunakan untuk mengetahui pengaruh variabel bebas terhadap variabel terikat. Sehingga analisis yang digunakan seharusnya menggunakan uji analisis covariat atau uji ancova. Karena uji ancova digunakan untuk mengetahui pengaruh perlakuan terhadap perubahan respon dengan mengontrol perubahan lain yang kuantitatif. Hasil yang didapat dari telaah 
terhadap sepuluh penelitian dengan menerapkan metodologi penelitian tindakan kelas (PTK) menunjukkan bahwa terjadi peningkatan secara signifikan dalam menerapkan metode demonstrasi Lestari (2012); Sukerti, dkk (2013); Nonik, dkk (2013); Hendrawati, dkk (2014); Adnyawati, dkk (2014); Ranaya (2013); Wahyuni, dkk (2014); Bartik (2013); Darlin, dkk (2013); dan Mistiyanti, dkk (2014). Maka dari itu, peneliti ingin menguji kembali pengaruh metode terhadap keterampilan berhitung siswa. Tujuan dari penelitian ini adalah untuk mengetahui pengaruh penerapan metode demonstrasi terhadap keterampilan berhitung siswa kelas 3 SD Negeri Kecandran 01 pada semester 2 tahun ajaran 2016/2017.

\section{Metode Penelitian}

Metodologi yang digunakan dalam penelitian ini adalah penelitian eksperimen. Jenis penelitian eksperimen yang digunakan adalah penelitian eksperimen semu (quasi esperimental research). Penelitian eksperimen semu bertujuan untuk mengungkapkan hubungan sebab akibat dengan cara melibatkan kelompok kontrol disamping kelompok eksperimen, namun pemilihan kedua kelompok tidak menggunakan teknik random. Pada penelitian ini dipilih metode eksperimen semu karena peneliti tidak mungkin mengkontrol semua variabel yang terkait dalam penelitian. Desain yang digunakan dalam penelitian ini adalah Nonequivalent Control Group Design (Sugiyono, 2010), karena dalam desain ini tidak dimungkinkan membagi siswa dalam satu kelas menjadi dua kelas.

Penelitian dilakukan di SDN Kecandran 01 dan SDN Dukuh 01. SDN Kecandran 01 sebagai kelas eksperimen dan SDN Dukuh 01 sebagai kelas kontrol. Peneliti memilih SDN Kecandran 01 dan SDN Dukuh 01, karena memiliki sifat-sifat yang ada dalam kelas 3 hampir sama seperti siswa memiliki keaktifan, semangat, motivasi, dan minat belajar yang sangat tinggi dan siswa juga mudah dikendalikan oleh peneliti.

Penelitian ini memiliki dua variabel penelitian yaitu variabel bebas dan variabel terikat. Variabel bebas dalam penelitian ini adalah metode demonstrasi. Yang dimaksud dengan metode demonstrasi dalam penelitian ini adalah metode pembelajaran yang mencakup 6 tahap yaitu 1) guru menyampaikan kompetensi pembelajaran; 2) guru memberikan urutan kegiatan pembelajaran; 3) guru menyiapakan alat dan bahan; 4) berdemonstrasi; 5) melakukan tanya jawab; dan 6) kesimpulan. Keberhasilan metode demonstrasi diukur melalui lembar observasi. Sementara itu, untuk variabel terikat dalam penelitian ini adalah keterampilan berhitung. Yang dimaksud keterampilan berhitung dalam penelititian ini adalah kemampuan kognitif yang dilihat dari hasil belajar siswa setelah diberikan soal pretest dan posttest.

Teknik pengumpulan data yang digunakan adalah teknik tes, karena keterampilan berhitung termasuk dalam ranah kognitif, sehingga teknik pengumpulan data harus melalui pengukuran yang nyata seperti mengerjakan butir soal. Instrumen pengumpulan data pada penelitian kali ini adalah dengan butir soal tes yang digunakan untuk mengetahui pengaruh metode demonstrasi terhadap keterampilan berhitung.

Teknik analisis data yang digunakan dalam penelitian ini adalah teknik uji ancova (Ary, 2010). Uji ancova digunakan untuk mengetahui pengaruh perlakuan terhadap perubahan respon dengan mengontrol perubahan lain yang kuantitatif. Prasayarat sebelum melakukan uji ancova adalah 1) uji homogenitas, uji homogenitas digunakan untuk mengetahui apakah varians dari kedua kelompok tersebut memiliki varians yang homogen; dan 2) uji normalitas digunakan untuk mengetahi apakah data yang diperoleh merupakan data yang berdistribusi normal atau tidak.

\section{Hasil dan Pembahasan}

\section{Hasil Penelitian}

Penelitian ini memiliki kelas eksperimen dan kelas kontrol. Siswa kelas 3 SDN Kecandran 01 dengan jumlah 32 siswa merupakan kelas eksperimen, sedangkan 32 siswa kelas 3 SDN Dukuh 01 adalah kelas kontrol dalam penelitian ini. Sebelum pembelajaran, kedua kelas tersebut dibagikan soal pretest untuk dikerjakan guna mengukur kemampuan siswa. Setelah pembelajaran selesai, maka langkah berikutnya adalah kelas eksperimen dan kelas kontrol dibagikan soal posttest untuk dikerjakan. Nilai siswa dalam mengerjakan soal pretest dan posttest digunakan untuk melakukan uji normalitas, uji homogenitas, dan uji hipotesis.

Hasil nilai siswa terhadap soal pretest dan postest dianalisis. Hasil analisis deskriptif untuk nilai pretest di kelas ekperimen memperoleh nilai terendah sebesar 35 dan nilai tertinggi sebesar 70 dengan rata-rata kelas sebesar 50 dari range nilai 0-100. Standar deviasi yang dihasilkan oleh kelas eksperimen adalah 9.837. Sementara itu, hasil analisis deskriptif untuk pretest di kelas kontrol memperoleh nilai terendah sebesar 35 dan nilai tertinggi sebesar 65 dengan rata-rata kelas sebesar 48.13 dengan standar 
deviasi sebesar 9.136. Berikut disajikan hasil analisis deskriptif nilai pretest di kelas eksperimen dan kelas kontrol dalam table 1.

Tabel 1. Analisis Deskriptif Nilai Pretest Siswa

\begin{tabular}{lrrrrr}
\hline \multicolumn{1}{c}{ Kelas } & N & Mean & $\begin{array}{c}\text { Std. } \\
\text { Deviation }\end{array}$ & Std. Error Mean \\
\hline Kelas Eksperimen & $\mathbf{3 2}$ & $\mathbf{5 0 . 0 0}$ & $\mathbf{9 . 8 3 7}$ & $\mathbf{1 . 7 3 9}$ \\
Kelas Kontrol & $\mathbf{3 2}$ & $\mathbf{4 8 . 1 3}$ & $\mathbf{9 . 1 3 6}$ & $\mathbf{1 . 6 1 5}$ \\
\hline
\end{tabular}

Hasil analisis deskriptif untuk nilai posttest di kelas eksperimen memperoleh nilai terrendah sebesar 75 dan nilai tertinggi sebesar 100 dengan rata-rata nilai kelas sebesar 88,59. Standar deviasi yang diperoleh dalam kelas eksperimen terhadap nilai posttest sebesar 8.351. Hasil analisis deskriptif terhadap nilai posttest dikelas kontrol memperoleh nilai terrendah sebesar 65 dan nilai tertinggi sebesar 95 dengan rata-rata nilai kelas sebesar 79,69. Standar deviasi yang diperoleh dalam kelas kontrol terhadap nilai posttest sebesar 8,418. Berikut disajikan hasil analisis deskriptif nilai posttest di kelas eksperimen dan kelas kontrol dalam tabel

Tabel 2. Analisis Deskriptif Nilai Posttest Siswa

\begin{tabular}{lcccc}
\hline \multicolumn{1}{c}{ Kelas } & $\mathrm{N}$ & Mean & $\begin{array}{c}\text { Std. } \\
\text { Deviation }\end{array}$ & $\begin{array}{c}\text { Std. Error } \\
\text { Mean }\end{array}$ \\
\hline Kelas Eksperimen & $\mathbf{3 2}$ & $\mathbf{8 8 . 5 9}$ & $\mathbf{8 . 3 5 1}$ & $\mathbf{1 . 4 7 6}$ \\
Kelas Kontrol & $\mathbf{3 2}$ & $\mathbf{7 9 . 6 9}$ & $\mathbf{8 . 4 1 8}$ & $\mathbf{1 . 4 8 8}$ \\
\hline
\end{tabular}

\section{Uji Normalitas}

Sebelum melakukan analisis ancova untuk mengetahui perbandingan kedua variabel maka perlu dilakukan analisis uji normalitas dan uji homogenitas terlebih dahulu. Hasil analisis uji normalitas terhadap nilai siswa dalam pretest dan posttest disajikan dalam tabel berikut

Tabel 3. Uji Normalitas Nilai Pretest One-Sample Kolmogorov-Smirnov Test

\begin{tabular}{|c|c|c|}
\hline \multicolumn{3}{|c|}{ Unstandardized Residual } \\
\hline $\mathrm{N}$ & & 64 \\
\hline Normal Parameters ${ }^{\mathrm{a}, \mathrm{b}}$ & Mean & 0.0000000 \\
\hline & Std. Deviation & 9.41756212 \\
\hline Extreme & Absolute & .093 \\
\hline Differences & Positive & .093 \\
\hline & Negative & -.068 \\
\hline Kolmogorov-Smirnov Z & & .744 \\
\hline Asymp. Sig. (2-tailed) & & .638 \\
\hline
\end{tabular}
a. Test distribution is Normal.

b. Calculated from data.

Berdasarkan hasil analisis uji normalitas terhadap nilai pretest pada kelas ekperimen dan kelas kontrol memperoleh nilai signifikansi sebesar 0,638. Disimpulkan bahwa signifikansi dari kedua kelas tersebut lebih besar dari alpha yang ditetapkan, yaitu $>0,05$, sehingga nilai pretest untuk kelas eksperimen dan kelas kontrol adalah normal. Hasil analisis uji normalitas terhadap nilai posttest untuk kelas eksperimen dan kelas kontrol disajikan pada tabel berikut

Tabel 4. Uji Normalitas Posttest

One-Sample Kolmogorov-Smirnov Test

\begin{tabular}{|c|c|c|}
\hline \multicolumn{3}{|c|}{ Unstandardized Residual } \\
\hline $\mathrm{N}$ & & 64 \\
\hline Normal Parameters ${ }^{\mathrm{a}, \mathrm{b}}$ & Mean & 0.0000000 \\
\hline & Std. Deviation & 8.31769366 \\
\hline Extreme & Absolute & .109 \\
\hline Differences & Positive & .099 \\
\hline & Negative & -.109 \\
\hline Kolmogorov-Smirnov Z & & .870 \\
\hline
\end{tabular}


a. Test distribution is Normal.

b. Calculated from data.

Berdasarkan hasil analisis uji normalitas soal posttest pada kelas ekperimen dan kelas kontrol memperoleh nilai signifikansi sebesar 0,436. Disimpulkan bahwa signifikansi dari kedua kelas tersebut lebih besar dari alpha yang ditetapkan, yaitu $>0,05$, sehingga nilai posttest untuk kelas eksperimen dan kelas kontrol adalah normal.

\section{Uji Homogenitas}

Setelah melakukan uji normalitas, prasyarat berikutnya untuk dapat melakukan uji ancova adalah uji homogenitas. Uji homogenitas digunakan untuk mengetahui homgenitas varians dari kedua kelas. Tabel dibawah merupakan hasil analisis uji homogenitas nilai pretest kelas eksperimen dan kelas kontrol

Tabel 5. Uji Homogenitas Nilai Pretest

Test of Homogeneity of Variances

\begin{tabular}{lccc}
\hline $\mathrm{Y}$ & & & \\
\hline Levene Statistic & $\mathrm{df1}$ & $\mathrm{df} 2$ & Sig. \\
$\mathbf{. 0 0 7}$ & $\mathbf{1}$ & $\mathbf{6 2}$ & $\mathbf{. 9 3 3}$ \\
\hline
\end{tabular}

Berdasarkan hasil analisis uji homogenitas nilai pretest, menunjukan bahwa perolehan nilai Levene Stastistic sebesar 0.007 dan nilai signifikasi sebesar 0,933 . Hal tersebut berarti uji homogenitas soal pretest bersifat homogen karena nilai signifikansi lebih besar dari pada nilai alpha $(0,933>0,05)$.

Tabel dibawah merupakan hasil analisis uji homogenitas nilai posttest pada kelas eksperimen dan kelas kontrol

Tabel 6. Uji Homogenitas Nilai Posttest

Test of Homogeneity of Variances

\begin{tabular}{llllll}
\hline Y & & & \\
\hline Levene Statistic & df1 & $\mathbf{1 f}^{\text {df2 }}$ & Sig. & \\
.093 & & $\mathbf{1}$ & $\mathbf{6 2}$ & & $\mathbf{7 6 2}$ \\
\hline
\end{tabular}

Berdasarkan hasil uji homogenitas nilai posttest, menunjukan bahwa perolehan nilai Levene Stastistic sebesar 0.093 dan nilai signifikasi sebesar 0,762 . Hal tersebut berarti uji homogenitas soal pretest bersifat homogen karena nilai signifikansi lebih besar dari pada nilai alpha $(0,762>0,05)$.

\section{Uji Hioptesis}

Berdasarkan hasil uji normalitas nilai pretest dan posttest, kedua kelas memiliki varian yang normal. Hasil analisis uji homogenitas nilai pretest dan posttest menunjukkan bahwa kedua kelas memiliki varian yang homogen atau sama. Prasyarat untuk melakukan analisis uji ancova sudah terpenuhi, maka data pretest dan posttest dapat dianalisis uji ancova. Uji ancova akan digunakan sebagai patokan untuk menguji hipotesis yang menyatakan bahwa ada pengaruh penerapan metode demonstrasi terhadap keterampilan berhitung siswa kelas 3 SDN Kecandran 01 pada semester 2 tahun ajaran 2016/2017. Berikut hasil uji ancova

Tabel 7. Hasil Uji Ancova

Tests of Between-Subjects Effects

Dependent Variable: Posttes

\begin{tabular}{lrrrrrr}
\hline Source & $\begin{array}{l}\text { Type I } \\
\text { Squares }\end{array}$ & Sum of df & Mean Square & F & \multicolumn{2}{l}{ Sig. } \\
\hline Corrected Model & & $\mathbf{1 4 7 8 . 3 7 6}^{\mathrm{a}}$ & $\mathbf{2}$ & $\mathbf{7 3 9 . 1 8 8}$ & $\mathbf{1 0 . 8 6 7}$ & $\mathbf{. 0 0 0}$ \\
Intercept & & $\mathbf{4 5 3 0 9 7 . 2 6 6}$ & $\mathbf{1}$ & $\mathbf{4 5 3 0 9 7 . 2 6 6}$ & $\mathbf{6 6 6 1 . 0 1 3}$ & $\mathbf{. 0 0 0}$ \\
Pretest & & $\mathbf{3 2 2 . 1 7 7}$ & $\mathbf{1}$ & $\mathbf{3 2 2 . 1 7 7}$ & $\mathbf{4 . 7 3 6}$ & $\mathbf{. 0 3 3}$ \\
Metode & & $\mathbf{1 1 5 6 . 1 9 9}$ & $\mathbf{1}$ & $\mathbf{1 1 5 6 . 1 9 9}$ & $\mathbf{1 6 . 9 9 7}$ & $\mathbf{. 0 0 0}$ \\
Demonstrasi & & $\mathbf{4 1 4 9 . 3 5 9}$ & $\mathbf{6 1}$ & $\mathbf{6 8 . 0 2 2}$ & & \\
Error & & & & & &
\end{tabular}




\begin{tabular}{lrr} 
Total & $\mathbf{4 5 8 7 2 5 . 0 0 0}$ & $\mathbf{6 4}$ \\
Corrected Total & $\mathbf{5 6 2 7 . 7 3 4}$ & $\mathbf{6 3}$ \\
\hline a. R Squared $=.263$ (Adjusted R Squared $=.239)$ \\
\hline
\end{tabular}

Berdasarkan hasil uji ancova diatas, menunjukan bahwa nilai $\mathrm{F}$ sebesar 10.867 dengan taraf signifikasi 0,000, karena signifikansi lebih kecil dari alpha atau 0,000<0,05 maka disimpulkan bahwa penerapan metode demonstrasi berpengaruh terhadap keterampilan berhitung siswa kelas 3. Pada kolom Intercept menunjukkan $\mathrm{F}$ sebesar 6661,013 dengan taraf signifikasi 0,000, signifikansi yang dihasilkan lebih kecil dari alpha atau $0,000<0,05$, maka disimpulkan bahwa nilai intercept signifikan. Pada kolom metode demonstrasi nilai $\mathrm{F}$ sebesar 16,997 dengan taraf signifikansi 0,000, karena signifikansi yang dihasilkan lebih kecil dari alpha maka metode demonstrasi dinyatakan signifikan. Data tersebut mengindikasikan bahwa terdapat pengaruh penerapan metode demonstrasi terhadap keterampilan berhitung siswa. Oleh karena itu dapat disimpulkan bahwa terdapat pengaruh penerapan metode demonstrasi terhadap keterampilan berhitung siswa pada pembelajaran matematika dengan materi menghitung keliling persegi dan persegi panjang di kelas 3 SD N Kecandran 01 pada semester 2.

\section{Pembahasan}

Metode demonstrasi menurut Sanjaya (2006:21) adalah metode yang cara pengelolaan pembelajarannya dengan memperagakan atau mempertunjukan kepada siswa suatu proses, situasi, benda, atau cara kerja suatu produk teknologi yang sedang dipelajari. Sedangkan Anitah W, (2008:5.25) mengungkapkan bahwa metode demonstrasi merupakan metode mengajar yang menyajikan bahan pelajaran dengan mempertunjukan secara langsung objek atau cara melakukan sesuatu sehingga, dapat mempelajarinya secara proses. Dua pendapat ahli memaparkan bahwa metode demonstrasi sangat membantu guru dalam menyampaikan sebuah materi pembelajaran, dimana materi ajar tersebut memuat sebuah proses melakukan sesuatu atau menentukan pengertian sesuatu. Hal tersebut sesuai dengan kegiatan hasil penelitian di kelas eksperimen dengan menerapkan metode demonstrasi untuk mata pelajaran matematika tentang menghitung keliling persegi dan persegi panjang. Banyak siswa yang menjadi paham, bersemangat dalam mengerjakan soal, serta siswa juga menjadi antusias dalam mengikuti pembelajaran. Dapat disimpulkan dari pendapat para ahli sebagaimana yang telah diuraikan terbukti bahwa metode demonstrasi sangat membantu guru dalam menyampaikan materi ajar yang sulit.

Huda (2010:233) mengungkapkan kelebihan metode demonstrasi dalam pembelajaran antara lain: 1) membuat pembelajaran menjadi lebih jelas dan lebih konkret; 2) memusatkan perhatian siswa pada pembelajaran; 3) lebih mengarahkan proses belajar siswa pada materi yang sedang dipelajari; 4) lebih melekatkan pengalaman dan kesan sebagai hasil pembelajaran dalam diri siswa; 5) membuat siswa lebih mudah memahami apa yang dipelajari; 6) membuat proses pengajaran lebih menarik; 7) merangsang siswa untuk aktif mengamati antar teori dengan kenyataan; 8) membantu siswa memahami dengan jelas jalannya suatu proses atau cara kerja suatu benda; 9) memudahkan berbagai jenis penjelasan; dan 10) memperbaiki kesalahan yang terjadi dari hasil ceramah melalui pengamatan dan contoh konkret dengan menghadirkan objek sebenarnya. Kelebihan metode demonstrasi dirasakan secara nyata oleh peneliti, seperti peneliti sangat terbantu dengan menerapkan metode demonstrasi dalam pembelajaran. Siswa menjadi konsentrasi saat pembelajaran berlangsung dan materi yang akan disampaikan menjadi mudah untuk dimengerti siswa.

Pendapat para ahli juga didukung dengan hasil-hasil penelitian terdahulu, seperti yang dilakukan oleh Mustokiyah (2013), dengan judul penelitiannya, "Penerapan Metode Demonstrasi Untuk Meningkatkan Hasil Belajar Siswa Pada Mata Pelajaran IPA Di Kelas II SD N Sidotopo Wetan I Surabaya”. Terbukti dari hasil penelitian yang telah dilakukannya, menunjukan bahwa hasil belajar siswa mengalami peningkatan sebesar 22,75\% yaitu dari $72,7 \%$ pada siklus I menjadi $95,45 \%$ pada siklus II. Selain Mustokiyah, Sahary (2016) juga melakukan penelitian dengan judul "Pengaruh Metode Demonstrasi Terhadap Kemahiran Menulis Karangan Narasi Siswa Kelas VIII Sekolah Menengah Pertama Negeri 19 Bintan Tahun Ajaran 2015/2016". Terbukti dari hasil penelitian yang telah dilakukannya menunjukan bahwa metode demonstrasi dapat mempengaruhi kemahiran menulis karangan narasi siswa. Seperti yang dilakukan Mustokiyah dan Sahary, Sodikin (2015) juga melakukan penelitian dengan judul "Penerapan Pembelajaran Berbasis Masalah Melalui Metode Demonstrasi Ditinjau dari Kemampuan Menggunakan Alat Ukur dan Sikap Ilmiah Siswa". Tetapi hasil penelitian dengan menerapkan metode demonstrasi tidak terdapat pengaruh terhadap kemampuan alat ukur dan sikap ilmiah siswa. Hal itu terjadi karena terlalu banyak variabel terikat yang diteliti, penelitian menggunakan kelas tidak homogen, dan uji analisisnya menggunakan uji anava. 
Penelitian yang dilaksanakan oleh peneliti, variabel terikat yang diteliti hanya keterampilan berhitung saja, kelas yang digunakan adalah kelas yang homogen, serta dalam uji hipotesis peneliti menggunakan uji ancova untuk mengetahui pengaruh metode demonstrasi terhadap keterampilan berhitung siswa. Hasil penelitian yang dilakukan oleh peneliti membuktikan bahwa terdapat pengaruh metode demonstrasi terhadap keterampilan berhitung siswa pada mata pelajaran matematika dalam materi menghitung keliling persegi dan persegi panjang. Dilihat dari rata-rata keterampilan berhitung siswa dikelas eksperimen sebesar 88,59 dan nilai rata-rata keterampilan berhitung siswa dikelas kontrol sebesar 79,69. Selisih keterampilan berhitung antara kelas eksperimen dan kelas kontrol sebesar 8,9.

Berdasarkan penelitian yang telah dilaksanakan, dapat diketahui bahwa metode demonstrasi mempengaruhi keterampilan berhitung siswa. Pembelajaran yang menerapkan metode demonstrasi dapat membuat siswa menjadi antusias, kreatif, dan aktif. Hal tersebut dibuktikan pada saat pembelajaran berlangsung, banyak siswa yang antusias untuk mendapatkan kesempatan mengerjakan soal dipapan tulis. Selain itu saat mengerjakan soal, terdapat beberapa siswa yang mengerjakan dengan rumus yang lebih sederhana dari pada rumus yang diberikan guru. Dapat disimpulkan bahwa keterampilan berhitung siswa meningkat jika dalam menyampaikan teori atau konsep dilakukan dengan cara memberikan contoh yang kongkret. Dengan menggunakan metode demonstrasi dalam pembelajaran, maka keterampilan berhitung siswa kelas eksperimen lebih tinggi dibandingkan kelas kontrol. Selain itu, dengan menggunakan metode demonstrasi pada kelas heterogen, didapatkan bahwa hasil keterampilan berhitung siswa pada kelas eksperimen dengan metode demonstrasi lebih tinggi dibandingkan dengan keterampilan berhitung siswa kelas kontrol yang menggunakan metode konvensional. Implikasi teoritis, setelah membandingkan teori demonstrasi dengan penelitian ini hasilnya adalah sejalan dan saling melengkapi. Selain itu dilihat dari rata-rata pada kelas eksperimen dengan menggunakan metode demonstrasi dan kelas kontrol menggunakan metode konvensional, didapat keterampilan berhitung kelas eksperimen mempunyai ketrampilan berhitung siswa yang lebih tinggi dibandingkan kelas kontrol. Dalam penelitian ini terbukti bahwa metode demonstrasi berpengaruh terhadap keterampilan berhitung matematika siswa; Implikasi praktis, pembelajaran dengan metode demonstrasi dapat digunakan sebagai salah satu metode pembelajaran yang dapat berpengaruh terhadap keterampilan berhitung siswa. Hal ini sejalan dengan penelitian yang dilakukan oleh Mistokiyah (2013) yang menyatakan bahwa metode demonstrasi dapat meningkatkan hasil belajar siswa. Dalam metode ini guru diperkenankan menyajikan materi dengan berdemonstrasi, kemudian guru dapat meminta siswa untuk berdemonstrasi seperti yang telah dicontohkan oleh guru. Dalam proses tersebut guru dapat menggali pengetahuan siswa melalui bertanya jawab mengenai demonstrasi yang telah dilakukan, dengan demikian maka pembelajaran dapat berjalan lebih efektif dan efisien, siswa pun menjadi aktif, kreatif, dan senang dalam mengikuti pembelajaran dengan menggunakan metode demonstrasi. Maka perlu diterapkan metode demonstrasi jika siswa dalam mengikuti pembelajaran di kelas cenderung pasif, dengan begitu siswa dalam mengikuti pembelajaran menjadi lebih aktif, tujuan pembelajaran akan lebih mudah untuk dicapai, dan hasil belajar dapat meningkat.

\section{Simpulan dan Saran}

Berdasarkan penelitian yang telah dilakukan, maka dapat disimpulkan bahwa terdapat pengaruh penerapan metode demonstrasi terhadap keterampilan berhitung siswa kelas 3 SDN Kecandran 01 Salatiga pada semester 2 tahun ajaran 2016/2017.

Berdasarkan analisis pembahasan dan simpulan yang telah dilakukan, untuk selanjutnya penulis memberikan saran teoritis yaitu metode demonstrasi yang diterapkan guru dapat berpengaruh terhadap keterampilan berhitung siswa. Pembelajaran dengan metode demonstrasi dapat membuat siswa aktif dan ikut berpartisipasi dalam pembelajaran metode demonstrasi. Dalam pembelajaran metode demonstrasi siswa ikut menentukan tingkat ketrampilan berhitung yang akan dicapai siswa.

Sedangkan saran secara praktis dijabarkan menjadi tiga bagian yaitu bagi sekolah, bagi guru, dan bagi siswa. Yang pertama bagi sekolah dapat membuat kebijakan untuk guru dalam mengajar supaya menggunakan metode demonstrasi dalam proses pembelajaran minimal 3 kali dalam 1 semester. Kedua, bagi guru, pembelajaran dengan metode demonstrasi hendaknya dapat digunakan guru dalam kegiatan pembelajaran di kelas untuk menciptakan suasana belajar yang aktif, tidak membosankan dan untuk meningkatkan hasil belajar siswa. dan yang ketiga saran bagi siswa adalah diharapkan dengan metode demonstrasi siswa dapat meningkatkan hasil belajar siswa terutama pada ketrampilan berhitung siswa dan dapat menjadikan motivasi siswa untuk lebih aktif, berani untuk berdemonstrasi di depan kelas pada saat pembelajaran sedang berlangsung. 


\section{Daftar Rujukan}

Adnyawati, N. D. M. S., Keluarga, J. P. K., \& Teknologi, F. P. 2004. Peningkatan Keterampilan Proses dan Hasil Pembelajaran Dekorasi Kue melalui Metode Demonstrasi dan Media Job Sheet Mahasiswa Jurusan PKK IKIP Negeri Singaraja. Jurnal Pendidikan dan Pengajaran ISSN, 0215-8250. ejournal.undiksha.ac.id

Anitah W, Sri, dkk. 2008. Strategi Pembelajaran di SD. Jakarta: Universitas Terbuka

Ary, D dkk. 2010. Introduction to Research in Education $8^{\text {th }}$. Belmont: Wadsworth Cengage Learning.

Bartik, A. 2013. Peningkatan Aktivitas Pembelajaran Matematika Dengan Penerapan Metode Demonstrasi di Kelas III SDN 11 Sungai Kunyit. Jurnal Pendidikan dan Pembelajaran, 2(7). jurnal.untan.ac.id

Darlina, R. 2013. Penerapan Metode Demonstrasi Untuk Meningkatkan Keterampilan Berbicara Bahasa Indonesia Kelas V SDN 31 Sungai Ambawang.Jurnal Pendidikan dan Pembelajaran, 2(1). jurnal.untan.ac.id

Ekasriadi, A, dkk. 2006. Metodologi Pengembangan Kemampuan Motorik dan Bahasa. Denpasar: IKIP PGRI Bali.

Firdus. 2014. Pengaruh Metode Pembelajaran Demonstrasi Terhadap Hasil Belajar Siswa Pada Materi Cahaya dalam Mata Pelajaran Sains Kelas V SDN 100/1 Pematang Gadung Kec. Mersam. Avalibele at http://www.e-campus.fkip.unja.ac.id/eskripsi/data/pdf/jurnal_mhs/artikel/A1D109144.pdf [accessed 27/05/2017]

Hendrawati, N. K. M., Ganing, N. N., Hum, M., \& Putra, D. K. N. S. 2014. Penerapan Metode Demonstrasi Melalui Kegiatan Melukis Dengan Cara Inkonvensional Untuk Meningkatkan Keterampilan Motorik Halus Pada Anak Kelompok B di TK Melati Payangan Gianyar. Jurnal Pendidikan Anak Usia Dini, 2(1). ejournal.undiksha.ac.id

Huda, M. 2015. Model-Model Pengajaran Dan Pembelajaran. Yogyakart: Pustaka Pelajar

Lestari, D. 2012. Upaya Meningkatkan Hasil Belajar Menggambar Buah-Buahan Dengan Menggunakan Metode Demonstrasi di Kelas VII Smp IT Al-Fityan School Medan. Gorga, 1(1). Jurnal.unimed.ac.id

Misiyanti, N. W., Parmiti, D. P., \& Wirya, N. 2014. Penerapan Metode Demonstrasi Berbantuan Media Konkret Melalui Kegiatan Kolase Untuk Meningkatkan Perkembangan Motorik Halus. Jurnal Pendidikan Anak Usia Dini, 2(1). ejournal.undiksha.ac.id

Mustokiyah. 2013. Penerapan Metode Demonstrasi Untuk Meningkatkan Hasil Belajar Siswa Pada Mata Pelajaran Ilmu Pengetahuan Aalam di Kelas II SD Negeri Sidotopo Wetan I Surabaya. Avalibele at http://www.e-jurnal.com/2014/02/penerapan-metode-demonstrasi-untuk.html_ [accessed 11/04/2017]

Nonik, N. N., Raga, I. G., \& Murda, I. N. 2013. Penerapan Metode Demonstrasi dengan Media Kartu Gambar untuk Meningkatkan Kemampuan Kognitif Anak Kelompok A di PAUD Widya Dharma Bondalem Tejakula. Jurnal Pendidikan Anak Usia Dini, 1(1). ejournal.undiksha.ac.id

Ranya, Z. A., Jamhari, M., \& Rede, A. 2014. Meningkatkan Hasil Belajar Siswa dalam Pembelajaran IPA Pokok Bahasan Panca Indra dengan Menggunakan Metode Demonstrasi pada Siswa Kelas 1VA SDN 5 Pusungi. Jurnal Kreatif Tadulako Online, 1(2). jurnal.untad.ac.id

Sabri, A. 2007. Strategi Belajar Mengajar Micro Teaching. Padang: Quantum Teaching.

Sahary. 2016. Pengaruh Metode Demonstrasi Terhadap Kemahiran Menulis Karangan Narasi Siswa Kelas VIII Sekolah Menengah Pertama Negeri 19 Bintan Tahun Ajaran 2015/2016. Avalibele at http://jurnal.umrah.ac.id/wp-content/uploads/gravity_forms/1-

ec61c9cb232a03a96d0947c6478e525e/2016/08/EJOURNAL-SAHARY120388201212-FKIP-2016PDF.pdf [accessed 27/05/2017]

Sanjaya. 2006. Pembelajaran Berbasis Kompetensi. Bandung: Kencana

Sodikin. 2015. Penerapan Pembelajaran Berbasis Masalah Melalui Metode Demonstrasi Ditinjau dari Kemampuan Menggunakan Alat Ukur dan Sikap Ilmiah Siswa. IAIN Raden Intan Lampung, Hlm 257269.

Sugiyono. 2010. Model Penelitian Pendidikan. Bandung: Alfabeta

Sukerti, N. M., Raga, G., \& Murda, I. N. 2013. Penerapan Metode Demonstrasi Berbantuan Media Daun Pisang Untuk Meningkatkan Keterampilan Motorik Halus Anak Melalui Kegiatan Menganyam Pada Anak Tk. Jurnal Pendidikan Anak Usia Dini, 1(1). ejournal.undiksha.ac.id

Susanto, A. 2013. Teori Belajar Dan Pembelajaran Di Sekolah Dasar. Jakarta : Prenada Media Group. UU No. 20 Tahun 2003 tentang Sistem Pendidikan Nasional

Wahyudi, Kriswandani. 2013. Pengembangan Pembelajaran Matematika. Salatiga: Widya Sari Press.

Wahyuni, N. N. R., Asri, I. G. A. S., \& Suniasih, N. W. 2014. Penerapan Metode Demonstrasi Melalui Kegiatan Mencetak Dengan Memanfaatkan Lingkungan Sebagai Sumber Belajar Untuk Meningkatkan Keterampilan Motorik Halus Pada Anak Kelompok B TK Kemala Bhayangkari 1 Denpasar. Jurnal Pendidikan Anak Usia Dini, 2(1). ejournal.undiksha.ac.id 